\title{
Late Blight of Potato and Tomato ${ }^{1}$
}

\author{
Ryan Donahoo and Pamela Roberts ${ }^{2}$
}

Fresh-market tomato is the most valuable vegetable crop in Florida. On average, 40,000 acres of tomatoes are commercially harvested in the state with a gross sales value in excess of $\$ 580$ million. Tomatoes are grown throughout the state with commercial production centered in five regions: southeast - Homestead (Miami-Dade, Martin, and Palm Beach Counties), east central - Ft. Pierce (St. Lucie County), southwest - Immokalee (Collier, Lee, and Hendry Counties), west central - Ruskin (Manatee and Hillsborough Counties), and northwest - Quincy (Gadsen County).

Florida's winter and early spring potato production ranks eleventh nationally based on market value. The state produces less than $2 \%$ of the United States' annual supply, although it accounts for nearly $35 \%$ of the winter crop produced on more than 35,000 acres, with an estimated value of more than $\$ 140$ million. The majority of potato production in Florida is centered in the Hastings area (St. Johns, Flagler, and Putnam Counties) and is planted in the spring; half of the crop is used for chips. The winter crop is produced to the south in the Homestead and Immokalee areas and is primarily used for table stock.

Both potato and tomato are susceptible to late blight, an aggressive disease capable of rapidly destroying entire fields. The disease is distributed worldwide and occurs wherever tomatoes or potatoes are grown and conditions favor disease development. Favorable conditions are typical for winter production in the south and spring production to the north, with cool temperatures $\left(50^{\circ} \mathrm{F}-70^{\circ} \mathrm{F}\right)$ and high relative humidity (> $80 \%$ ) associated with heavy dew or fog and prolonged periods of leaf wetness (Fig. 1A).

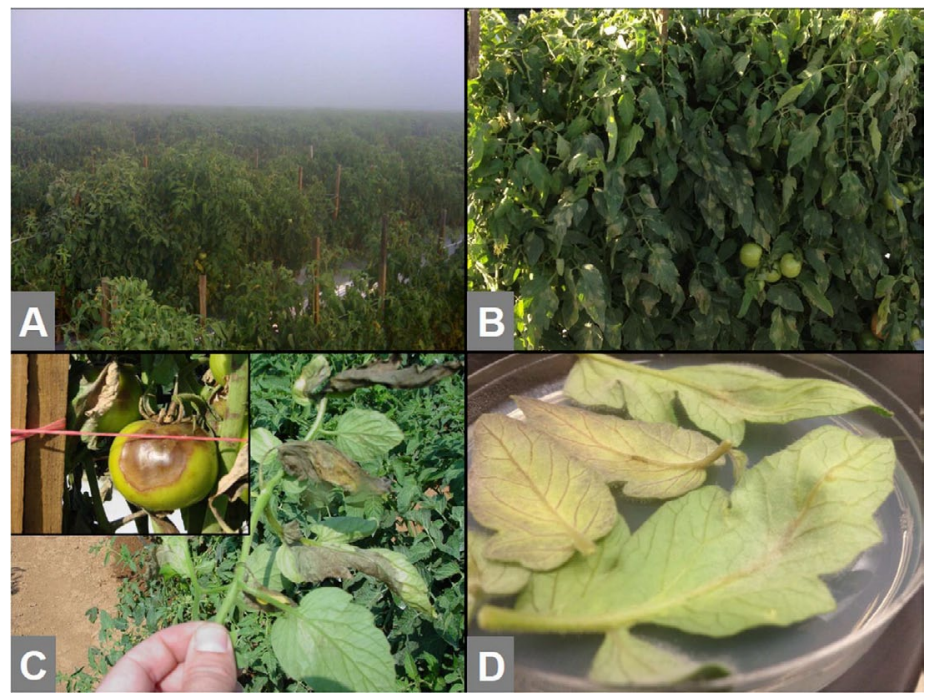

Figure 1. 1A. Cool, foggy weather that occurs during winter tomato production in Florida is ideal for late blight disease development. B. Tomato leaves heavily symptomatic for late blight lesions. C. Late blight lesions on fruit and leaves. D. Tomato leaves on water agar to induce sporulation of Phytophthora infestans, which can be observed as the white, fluffy structures on the leaf surface.

\section{Late Blight Symptoms}

Late blight symptoms are similar on potato and tomato. With the exception of roots, all parts of the plants are susceptible, and leaves, stems, and fruit can be infected (Fig. $1 \mathrm{~B}$ and $1 \mathrm{C})$. Leaf symptoms may begin as dark green water soaking that may be associated with chlorosis or necrosis,

1. This document is PP301, one of a series of the Plant Pathology Department, Florida Cooperative Extension Service, Institute of Food and Agricultural Sciences, University of Florida. Original publication date December 2012. Visit the EDIS website at http://edis.ifas.ufl.edu.

2. Ryan Donahoo, researcher, and Pamela Roberts, professor, Department of Plant Pathology, University of Florida Institute of Food and Agricultural Sciences, Southwest Florida REC, Immokalee, FL 34142. 
depending upon the age of the lesion and the weather conditions. Under relative humidity in excess of $80 \%$, lesions may appear purple to black with white sporangial growth. Under hotter and drier conditions, the lesions turn brown, dry out, and appear papery.

\section{About the Late Blight Pathogen}

Late blight is caused by Phytophthora infestans, a pathogen that is a member of a group of organisms often referred to as oomycetes or water molds. Once recognized as a member of the kingdom Fungi, $P$. infestans and other members in the genus Phytophthora are now classified in a distinct taxonomic group known as oomycetes in the kingdom Chromista. Key features of oomycetes include sexual reproduction resulting in the formation of oospores $(P$. infestans requires both $\mathrm{A} 1$ and $\mathrm{A} 2$ mating types in contact with one another) and asexual reproduction resulting in the production of sporangia (spores) and subsequent release of motile zoospores (special spores that are capable of moving with the aid of whip-like structures called flagella). Late blight sporangia are readily dispersed by wind and rain and can easily move over long distances with frontal weather systems during the production season. Under ideal conditions like those associated with cold fronts, individual sporangia can release dozens of motile zoospores, thus rapidly increasing the levels of inoculum and inciting epidemics. The late blight pathogen, $P$. infestans, is considered a hemi-biotroph that is capable of growing through host tissue for days without any obvious signs of infection. This characteristic can hinder detection, which typically requires the visualization of sporangia (Fig 1D).

While both A1 and A2 mating types have been observed in Florida, there is no evidence for sexual reproduction occurring. Similarly, sexual reproduction has yet to be reported occurring elsewhere in the United States. Although occasionally there has been more than one genotype (also referred to as clonal lineage or strain) in the state in a season, most late blight epidemics in Florida have historically been the result of a single genotype. Depending upon the genotype, isolates may exhibit a preference for potato, such as US-8, or tomato, such as US-20 or US- 21 . Other genotypes may be found on both hosts. In the year prior to and following the late blight pandemic of 2009, US-22 was recovered from both potato and tomato production throughout Florida (Table 1).

\section{Sources of Late Blight}

It has been well documented that individual genotypes of $P$. infestans are capable of global movement on tubers (Goodwin et al. 1994). Similarly, potato late blight outbreaks originating on seed potato obtained from a variety of northern producers were attributable to the appearance of clonal lineages US-1, US-6, and US-7 in Florida (Goodwin et al. 1995). The US-8 genotype was likely repeatedly introduced on seed potato, impacting all production regions in Florida during the 1990s. In the spring of 2012, the US-24 clonal lineage appeared first in a potato field around Immokalee and was recovered from nearby tomatoes within 2 weeks. This demonstrated that tomatoes in proximity to the potato can be infected, although the pathogen genotype may prefer potato. A recent analysis of the late blight populations in Florida further demonstrated that US-24 was present in northern states 1-2 years before appearing in Florida potatoes.

Sources of late blight inoculum for tomato are less obvious, particularly in the absence of nearby infected potatoes. In 2005 and 2006, late blight was only observed in southwest Florida when US-20 and US-21 were identified exclusively on tomatoes in Florida and North Carolina (Hu et al. 2012; Schultz et al. 2010).

\section{Controlling Late Blight}

Although late blight is not known to be seed-borne in tomatoes, growers should purchase disease-free transplants. However, potato tubers can be infested with the pathogen, so certified seed potatoes should be used to reduce the risk of inoculum. When possible, potato seed pieces should be stored dry and examined prior to planting. Although there is potential for inoculum to spread on seed in storage under preplanting conditions, the risk of spread is typically greatest at seed cutting. In the field, any volunteer tomato or potato plants should be destroyed, particularly those in locations that would not be sprayed when making routine fungicide applications. Similarly, cull piles of potatoes should be destroyed well before the next growing season. Host resistance is usually highly effective for disease management. While there are late blight-resistant potato varieties suitable for Florida, no commercial resistant tomato varieties suitable for Florida production are currently available, although resistance genes (ph2 and 3) have been successfully used in cultivars grown in other production regions.

If late blight is to be successfully controlled, regular scouting is imperative, especially during periods of cool, wet 
weather. Fungicides should be applied preventatively when late blight is found in the area, or when weather conditions are favorable. Favorable conditions are cool temperatures $\left(50^{\circ} \mathrm{F}-70^{\circ} \mathrm{F}\right)$ coupled with extended leaf wetness, such as during high humidity ( $>80 \%$ ) or rain events associated with heavy dew or fog. A broad-spectrum, contact fungicide is suitable for preventative sprays. When late blight is present and additional control is needed, fungicides that specifically target oomycetes may be added to the program. Additionally, when weather conditions are conducive for late blight and control efforts appear less than satisfactory, the interval between fungicide applications may need to be shortened. In the potato-producing region around Hastings, Florida, a forecasting system may be useful to alert growers of favorable conditions and to assist with the timing of fungicide applications. At present, a forecasting system appears less useful in south Florida since ideal weather conditions may be present throughout most of the production season.

When harvesting potatoes, the foliage should be killed to reduce the risk of infecting tubers. The harvested crop should be stored under recommended postharvest conditions. Any tuber with symptoms of late blight should be immediately discarded to prevent infecting other tubers during storage or shipping.

\section{Additional Resources}

USABlight - U.S. Occurrence Map, Additional Photos and Information

http://www.usablight.org/

Disease Control for Florida Tomatoes

http://edis.ifas.ufl.edu/vh056

Vegetable Production Handbook for Florida

- Chapter 17. Potato Production in Florida (Fungicide Table)

http://edis.ifas.ufl.edu/cv131

- Chapter 23. Tomato Production in Florida

http://edis.ifas.ufl.edu/cv137

\section{References}

Fry, W. E., M. T. McGrath, A. Seaman, T. A. Zitter, A. McLeod, G. Danies, I. Small et al. 2012. “The 2009 Late Blight Pandemic in Eastern USA.” APSnet Features. http://www.apsnet.org/publications/apsnetfeatures/ Pages/2009LateBlight.aspx.
Goodwin, S. B., B. A. Cohen, and W. E. Fry. 1994.

"Panglobal Distribution of a Single Clonal Lineage of the Irish Potato Famine Fungus." Proceedings of the National Academy of Science 91 (24): 11591-11595.

Goodwin, S. B., C. D. Smart, R. W. Sandrock, K. L. Deahl, Z. K. Punja, and W. E. Fry. 1998. "Genetic Change within Populations of Phytophthora infestans in the United States and Canada during 1994 to 1996: Role of Migration and Recombination." Phytopathology 88 (9): 939-949.

Goodwin, S. B., L. J. Sujkowski, A. T. Dyer, B. A. Fry, and W. E. Fry. 1995. "Direct Detection of Gene Flow and Probable Sexual Reproduction of Phytophthora infestans in Northern North America." Phytopathology 85 (4): 473-479.

Hu, C. H., F. G. Perez, R. S. Donahoo, A. McLeod, K. Myers, K. Ivors, G. Secor, P. D. Roberts, K. Deahl, W. E. Fry, and J. B. Ristaino. 2012. "Recent Genotypes of Phytophthora infestans in the Eastern United States Reveal Clonal Populations and Reappearance of Mefenoxam Sensitivity." Plant Disease 96 (9): 1323-1330.

Schultz, D., R. S. Donahoo, F. G. Perez, S. Tejeda, P. D. Roberts, and K. L. Deahl. 2010. "A Survey of Tomato and Potato Fields in Florida Reveals Unique Genotypes of Phytophthora infestans between 2005 and 2007." Hort. Science 45 (7): 1064-1068.

Shattock, R. C. 1988. "Studies on the Inheritance of Resistance to Metalaxyl in Phytophthora infestans." Plant Pathology 37: 4-11. 
Table 1. Years observed, geography, host, and characteristics of $P$. infestans clonal lineages observed in Florida

\begin{tabular}{|c|c|c|c|c|c|}
\hline Year & Area $^{\mathrm{a}}$ & Host & Clonal lineage & Mating type & Mefenoxam sensitivity ${ }^{b}$ \\
\hline 1991 and before & All & Potato & US-1 & A1 & \\
\hline $1993^{c}$ & Immokalee & Potato & US-1 & A1 & \\
\hline $1993^{c}$ & Tampa, Hastings & Tomato/potato & US-6 & A1 & \\
\hline $1993^{c}$ & Tampa, Hastings & Tomato/potato & US-7 & A2 & Resistant \\
\hline $1994^{d}$ & Hastings & Potato & US-8 & A2 & $\mathrm{R}$ \\
\hline $1994^{d}$ & Tampa & Tomato & US-7 & & $\mathrm{R}$ \\
\hline $1995^{d}$ & Tampa & Tomato & US-7 & & \\
\hline $1995^{d}$ & Immokalee, Tampa & Tomato/potato & US-8 & & \\
\hline $1996^{d}$ & Immokalee & Tomato & US-17 & & \\
\hline $2004^{e}$ & Immokalee & Tomato & US-20 & A2 & Intermediate \\
\hline $2005^{\mathrm{e}}$ & Immokalee & Tomato & US-20 & A2 & I \\
\hline $2006^{e}$ & Immokalee & Tomato & US-21 & A2 & I \\
\hline $2007^{e}$ & Immokalee & Tomato & US-21 & $\mathrm{A} 2$ & 1 \\
\hline $2008^{f g}$ & All & Tomato/potato & US-22 & A2 & Sensitive \\
\hline $2009^{f g}$ & All & Tomato/potato & US-22 & A2 & $S$ \\
\hline $2010^{\mathrm{fg}}$ & All & Tomato/potato & US-22 & $\mathrm{A} 2$ & $S$ \\
\hline 2011 & Homestead & Potato & US-24 & A1 & $S$ \\
\hline 2011 & Immokalee & Tomato & US-23 & A1 & $S$ \\
\hline 2012 & Immokalee, Tampa & Tomato & US-11 & A1 & $\mathrm{R}$ \\
\hline 2012 & Immokalee & Potato & US-8 & A2 & S-I \\
\hline 2012 & Immokalee & Tomato/potato & US-24 & A1 & S-I \\
\hline 2012 & Homestead & Tomato & US-23 & A1 & $S$ \\
\hline \multicolumn{6}{|c|}{$\begin{array}{l}\text { a Production regions are geographically located: Immokalee = southwest; Tampa = west central; Hastings = northeast; Homestead = southeast. } \\
\text { b Criteria of (Shattock 1988) to determine R= Resistant; I= Intermediate; or S= Sensitive to mefenoxam } \\
\text { c (Source: Goodwin et al. 1995) US-1 six states in } 1992 \text { then in FL in 1993. US-1 dominant genotype until 1989. US-1 in SWFL initiated by ND and } \\
\text { ME seed. } \\
\text { d (Source: Goodwin et al. 1998) } \\
\text { e(Source: Schultz et al. 2010) } \\
\text { f (Source: Hu et al. 2012) } \\
\text { g(Source: Fry et al. 2012) }\end{array}$} \\
\hline
\end{tabular}

